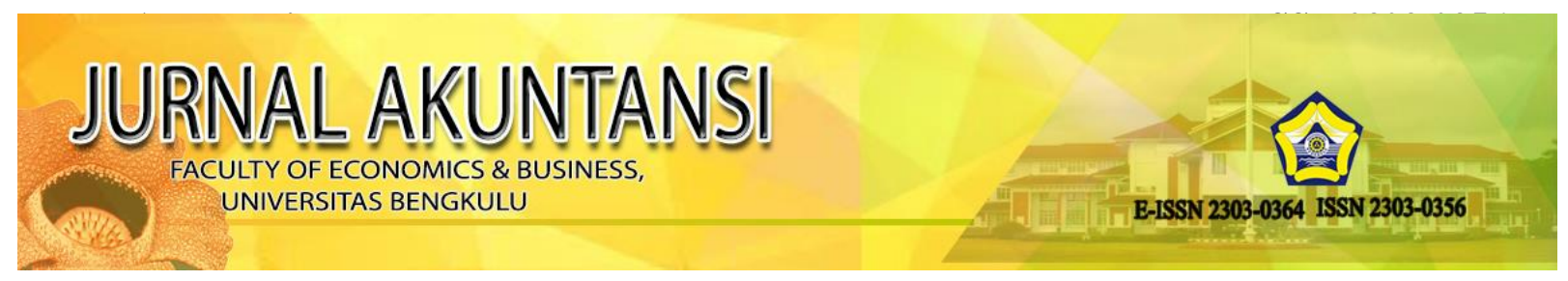

\title{
PENGENDALIAN INTERN PEMERINTAH DAN AKUNTABILITAS PUBLIK TERHADAP KINERJA INSTANSI PEMERINTAH DI KOTA BENGKULU ( Studi Pada OPD Kota Bengkulu )
}

\section{GOVERNMENT INTERNAL CONTROL AND PUBLIC ACCOUNTABILITY TOWARDS GOVERNMENT INSTITUTION PERFORMANCE IN BENGKULU CITY. (Study in OPD BENGKULU CITY)}

\author{
Nur Cholis ${ }^{1}$ ), Fadli $^{2}$ ) \\ Universitas Bengkulu, Jl. WR. Supratman,Kandang Limun, Muara Bangkahulu, Bengkulu \\ nurcholis@gmail.com ${ }^{l}$ ),fadli_abdullah@yahoo.com²)
}

\begin{abstract}
This research is a quantitative research that aims to see whether there is influence of information technology utilization, internal control system of government and public accountability to performance of government institution. This study uses the Organization of Regional Devices (OPD) Bengkulu City as a sample of research. The sample selection in this research is done by using purposive sampling method. Hypothesis testing in this study used Multiple Linear Regression Analysis with the help of SPSS program and 5\% significance level $(0,05)$. The result of the test is 1) there is significant influence of the utilization of information technology to the performance of government institution, 2) there is significant influence of internal control system of government performance of government institution, 3) there is significant influence of public accountability to performance of government institution.
\end{abstract}

Key Words: Technology, System, Accountability, Government

\section{ABSTRAK}

Penelitian ini merupakan penelitian kuantitatif yang bertujuan untuk membuktikan apakah ada pengaruh pemanfaatan teknologi informasi, sistem pengendalian intern pemerintah dan akuntabilitas publik terhadap kinerja instansi pemerintah. Penelitian ini menggunakanOrganisasi Perangkat Daerah (OPD) Kota Bengkulu sebagai sampel penelitian. Pemilihan sampel dalam penelitian ini dilakukan dengan menggunakan metode purposive sampling. Pengujian hipotesis dalam penelitian ini menggunakan Analisis Regresi Linear Berganda dengan bantuan program SPSS dan tingkatan signifikansi 5\% (0,05). Hasil dari pengujian tersebut adalah 1) terdapat pengaruh signifikan pemanfaatan teknologi informasi terhadap kinerja instansi pemerintah, 2) terdapat pengaruh signifikan sistem pengendalian intern pemerintah kinerja instansi pemerintah, 3) terdapat pengaruh signifikan akuntabilitas publik terhadap kinerja instansi pemerintah.

Kata Kunci : Teknologi, Sistem, Akuntabilitas, Pemerintah

\section{PENDAHULUAN}

Perangkat Daerah atau Organisasi Perangkat Daerah ( OPD) merupakan organisasi atau lembaga pada Pemerintah Daerah yang bertanggung jawab kepada Kepala Daerah dalam rangka penyelenggaraan pemerintahan di daerah. Perangkat Daerah dibentuk oleh masingmasing daerah berdasarkan pertimbangan karakteristik, potensi, dan kebutuhan Daerah. Berdasarkan Permendagri No 18 tahun 2016 tentang perangkat Daerah yang tertera pada pasal 
5 menerangkan bahwa perangkat daerah Kabupaten/Kota meliputi sekretariat daerah, sekretariat DPRD, inspektorat, dinas, badan dan kecamatan.

Tugas utama pemerintah sebagai organisasi sektor publik adalah menciptakan kesejahteraan masyarakat. Kesejahteraan masyarakat merupakan sebuah konsep yang sangat multikompleks. Kesejahteraan masyarakat tidak hanya berupa kesejahteraan fisik yang bersifat material saja, namun termasuk kesejahteraan nonfisik yang bersifat immaterial (Mahmudi, 2005:8).

Kinerja merupakan kondisi yang harus diketahui dan diinformasikan kepada pihakpihak tertentu untuk mengetahui tingkat pencapaian hasil suatu instansi dihubungkan dengan visi yang diemban suatu organisasi serta mengetahui dampak positif dan negatif suatu kebijakan operasional yang diambil (Nasir dan Oktari,2013).

Salah satu faktor yang mempengaruhi kinerja instansi pemerintah adalah pemanfaatan teknologi informasi. Penelitian Nasir dan Oktari (2013) menyebutkan bahwa perkembangan teknologi informasi direspon oleh organisasi dengan mendesain sistem informasi berbasis teknologi komputer atau website. Sistem informasi yang didukung TI dapat memberikan nilai tambah bagi organisasi jika didesain menjadi sistem informasi yang efektif. Kinerja organisasi sangat dipengaruhi oleh penguasaan teknologi informasi dari karyawan suatu organisasi.

Faktor kedua yang berpengaruh terhadap kinerja adalah pengendalian intern. Dalam PP No. 60 Tahun 2008, Sistem Pengendalian Intern Pemerintah (SPIP) adalah sistem pengendalian intern yang diselenggarakan secara menyeluruh di lingkungan pemerintah pusat dan pemerintah daerah. Pengawasan intern adalah seluruh proses kegiatan auidit, reviu, evaluasi, pemantauan dan kegiatan pengawasan lain terhadap penyelenggaraan tugas dari fungsi organisasi dalam rangka memberikan keyakinan yang memadai bahwa kegiatan telah dilaksanakan sesuai dengan tolak ukur yang telah ditetapkan secara efektif dan efisien untuk kepentingan pimpinan dalam mewujudkan tata pemerintahan yang baik.

Faktor ketiga yang juga mempengaruhi kinerja adalah akuntabilitas publik Akuntabilitas dapat diartikan sebagai bentuk pertanggungjawaban keberhasilan atau kegagalan pelaksanaan misi organisasi dalam mencapai tujuan dan sasaran yang telah ditetapkan sebelumnya, melalui suatu media pertanggungjawaban yang dilaksanakan secara periodik. Pada dasarnya, akuntabilitas adalah pemberian informasi dan pengungkapan atas aktivitas dan kinerja finansial kepada pihak-pihak yang berkepentingan. Pemerintah, baik pusat maupun daerah harus dapat dapat menjadi subyek pemberi informasi dalam rangka pemenuhan hak-hak publik yaitu hak untuk tahu, hak untuk diberi informasi dan hak untuk didengar partisipasinya (Irfan, 2016).

Dari Laporan Kinerja Instansi Pemerintah (LkjIP) Kota Bengkulu tahun 2016 di sebutkan bahwa secara umum pencapaian sasaran dan pelaksanaan program/kegiatan tahun 2016 telah dilaksanakan sesuai dengan rencana dan Jika dilihat dari sisi realisasi, baik secara fisik maupun keuangan secara umum dapat dijelaskan bahwa pada Tahun 2016 kinerja instansi kota bengkulu sudah mengalami peningkatan. Tetapi di sisi lain masih terdapat beberapa kendala dalam pelaksanaan kegiatan, yakni terkait dengan konsistensi perencanaan dan implementasi program, sinergitas antara program yang satu dengan lainnya serta keterbatasan anggaran dalam menunjang program pembangunan. Dengan adanya laporan kinerja ini, Pemerintah Kota Bengkulu telah mencoba mempertanggungjawabkan segala upaya yang telah dilaksanakan dalam mencapai Visi dan Misi Pemerintah Kota Bengkulu yang tertuang dalam Rencana Pembangunan Jangka Menengah Daerah (RPJMD) 2013-2018.

\section{Rumusan Masalah}

1. Apakah pemanfaatan teknologi informasi berpengaruh positif terhadap kinerja instansi pemerintah? 
2. Apakah sistem pengendalian intern pemerintah berpengaruh positif terhadap kinerja instansi pemerintah?

3. Apakah akuntabilitas publik berpengaruh positif terhadap kinerja instansi pemerintah?

\section{Tujuan}

Tujuan dari penelitian ini adalah untuk membuktikan pengaruh pemafaatan teknologi informasi, SPIP dan akuntabilitas publik terhadap kinerja instansi OPD di Kota Bengkulu.

\section{KERANGKA TEORITIS DAN HIPOTESIS}

\section{Kinerja Instansi Pemerintah}

Kinerja berasal dari kata job performance atau actual performance yang prestasi sesungguhnya yang dicapai seseorang atau organisasi. Pengertian kinerja (prestasi kerja adalah hasil kerja secara kualitas dan kuantitas yang dicapai oleh seseorang pegawai atau suatu organisasi dalam melaksanakan funsginya sesuai dengan tanggungjawab yang diberikan (Riadi, 2012). Mahmudi (2007 :14) tujuan dilakukannya pengukuran kinerja pada organisasi sektor publik yaitu Mengetahui tingkat ketercapaian tujuan organisasi, Menyediakan sarana pembelajaran bagi pegawai, Memperbaiki kinerja untuk periode berikutnya, Memberikan pertimbangan yang sistematik dalam pembuatan keputusan pemberian reward dan punishmen, Memotivasi pegawai dan Meciptakan akuntabilitas.

\section{Sistem Pengendalian Intern Pemerintah}

Dalam PP No. 60 Tahun 2008, SPI (Sistem Pengendalian Intern) adalah proses yang integral pada tindakan dan kegiatan yang dilakukan secara terus menerus oleh pimpinan dan seluruh pegawai untuk memberikan keyakinan memadai atas tercapainya tujuan organisasi melalui kegiatan yang efektif dan efisien, keandalan pelaporan keuangan, pengamanan aset negara, dan ketaatan terhadap peraturan perundang-undangan. Rai (2011) menyatakan bahwa SPI merupakan kebijakan dan prosedur yang dirancang untuk memberikan keyakinan bagi manajemen bahwa organisasi mencapai tujuan dan sasarannya. Berkenaan dengan komponen atau unsur pengendalian intern, SPIP (Sistem Pengendalian Intern Pemerintah) dalam UU No. 60 tahun 2008 terdiri atas beberapa unsur diantaranya lingkungan pengendalian, penilaian resiko, pengendalian resiko, informasi dan komunikasi dan pemantauan.

\section{Akuntabilitas Publik}

Mahsun (2011) akuntabilitas dapat dipahami sebagai kewajiban pihak pemegang amanah (agent) untuk memberikan pertanggungjawaban, menyajikan, melaporkan dan mengungkapkan segala aktivitas dan kegiatan yang menjadi tanggung jawabnya kepada pihak pemberi amanah (principal) yang memiliki hak dan wewenang untuk meminta pertanggungjawaban tersebut. Sadjiarto (2000) akuntabilitas dapat dipandang dari berbagai perspektif. Dari perspektif akuntansi, American Accounting Association menyatakan bahwa akuntabilitas suatu entitas pemerintahan dapat dibagi dalam empat kelompok, yaitu akuntabilitas terhadap Sumber daya finansial, Kepatuhan terhadap aturan hukum dan kebijaksanaan administratif, Efisiensi dan ekonomisnya suatu kegiatan. Hasil program dan kegiatan pemerintah yang tercermin dalam pencapaian tujuan, manfaat dan efektivitas. 


\section{Perumusan Hipotesis}

Penggunaan teknologi informasi dapat meningkatkan hubungan antara pemerintah dan pihak-pihak lain. Manfaat yang dapat dirasakan antara lain yaitu pelayanan yang lebih baik kepada masyarakat, peningkatan hubungan antara pemerintah, pelaku bisnis, dan masyarakat umum, pemberdayaan masyarakat melalui informasi yang mudah diperoleh dan pelaksanaan pemerintahan yang lebih efisien (Syaifullah, 2013).

H1: Pemanfaatan Teknologi Informasi Berpengaruh Positif Terhadap Kinerja Instansi Pemerintah.

Dalam PP No. 60 Tahun 2008, Sistem Pengendalian Intern adalah proses yang integral pada tindakan dan kegiatan yang dilakukan secara terus menerus oleh pimpinan dan seluruh pegawai untuk memberikan keyakinan memadai atas tercapainya tujuan organisasi melalui kegiatan yang efektif dan efisien, keandalan pelaporan keuangan, pengamanan aset negara, dan ketaatan terhadap peraturan perundang-undangan.

$\mathrm{H}_{2}$ : Sisitem Pengendalian Intern Pemerintah Berpengaruh Positif Terhadap Kinerja Instansi Pemerintah.

Akuntabilitas publik adalah kewajiban pihak pemegang amanah (agent) untuk memberikan pertanggungjawaban, menyajikan, melaporkan, dan mengungkapkan segala aktivitas dan kegiatan yang menjadi tanggung jawabnya kepada pihak pemberi amanah (principal) yang memiliki hak dan kewenangan untuk meminta pertanggungjawaban tersebut (Mardiasmo, 2002).

$\mathrm{H}_{3}$ : Akuntabiltas Publik Berpengaruh Positif Terhadap Kinerja Instansi Pemerintah.

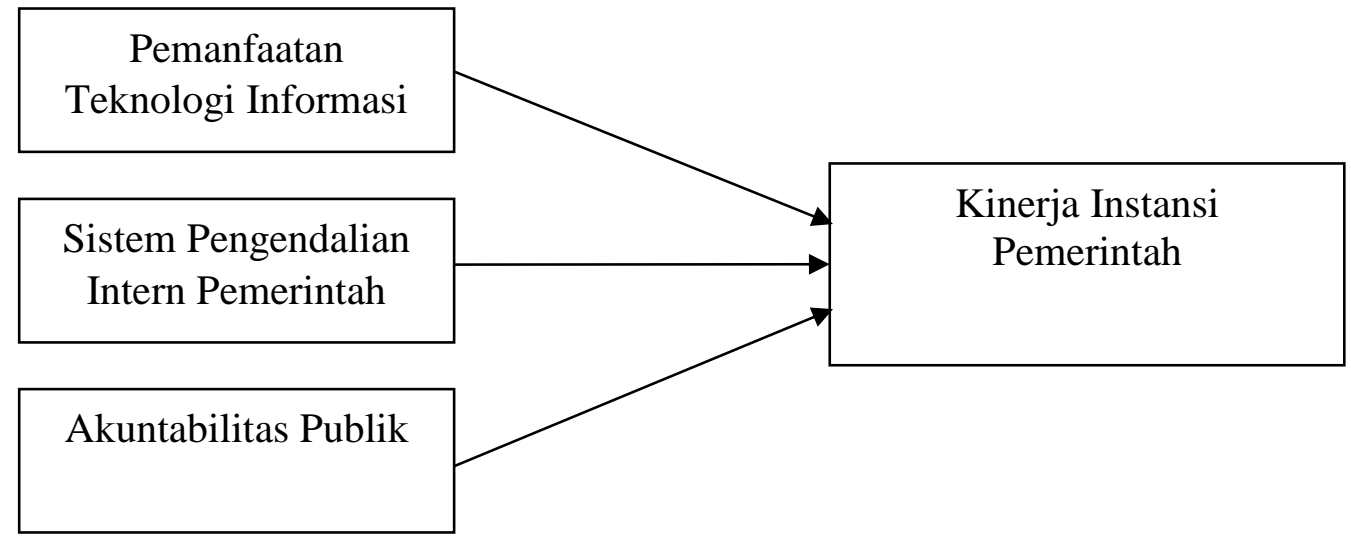

METODE PENELITIAN

\section{Jenis Penelitian}

Jenis penelitian ini adalah jenis penelitian kuantitatif. Menurut Sugiyono (2010) metode penelitian kuantitatif merupakan metode penelitian yang berlandaskan pada filsafat, digunakan untuk meneliti pada populasi atau sampel tertentu, pengumpulan data menggunakan instrumen penelitian, analisis data bersifat kuantitatif atau statistik, dengan tujuan menguji hipotesis yang ditetapkan.

\section{Definisi Operasional dan Pengukuran Variabel}

Variabel dependen dalam penelitian ini adalah kinerja instansi Pemerintah dan variabel independen dalam penelitian ini adalah pemanfaatan teknologi informasi, SPIP dan akuntabilitas publik dalan untuk perhitungan dalam penelitian ini menggunakan sklala Likert $1-5$. 


\section{Populasi dan Sampel}

Populasi dalam penelitian ini adalah seluruh instansi pemerintah Kota Bengkulu sedangkan sampel dalam penelitian ini adalah institusi/lembaga yang meliputi Sekretariat, inspektorat, dinas, badan, dan kecamatan pada Pemerintah Kota Bengkulu yang terdiri dari 38 OPD. Responden masing-masing diambil satu dari setiap OPD. Responden dalam penelitian ini adalah Kepala Dinas instansi terkait.

\section{Metode Pengambilan sampel}

Pemilihan sampel dilakukan dengan menggunakan metode purposive sampling dengan tujuan untuk mendapatkan sampel representatif sesuai dengan kriteria yang ditentukan.Adapun kriteria sampel yang akan digunakan yaitu : Instansi yang telah dipimpin oleh kepala dinas minimal 1 tahun, dengan pertimbangan bahwa telah memiliki pengalaman $\geq 1$ tahun dianggap memiliki pengalaman yang cukup dalam pertanggungjawaban dan penyusunan kinerja OPD Kota Bengkulu.

\section{Metode Pengumpulan Data}

Jenis data dalam penelitian ini adalah data primer. Dimana data yang didapat atau diperoleh secara langsung dari objek yang akan diteliti. Dalam penelitian ini metode yang digunakan untuk mengumpulkan data primer adalah metode survey.

\section{Metode Analisis}

\section{Statistik Deskriptif}

Anallisis deskriptif dalam penelitian ini disajikan untuk memberikan suatu gambaran mengenai karakteristik variabel penelitian, diantaran yaitu nilai minimum, nilai maximum, nilai mean dan standar deviasi.

\section{Uji Kualitas Data}

Uji validitas dilakukan dengan melihat korelasi antara skor butir pernyataan dengan total skor variabel menggunakan atau melalui program SPSS. Dasar pengambilan keputusan adalah jika $r_{\text {hitung }}>r_{\text {tabel }}$ dengan tingkat signifikan 5\%. Teknik yang digunakan untuk pengujian validitas dalam penelitian ini dilakukan dengan menggunakan koefisien korelasi product moment pearson dengan menggunakan SPSS versi 16.0. Suatu konstruk atau variabel dikatakan reliabel atau handal jika memiliki nilai Cronbach Alpha > 0,70. Apabila Cronbach Alpha dari suatu variabel $>0,70$ maka butir pertanyaan dalam instrumen penelitian tersebut adalah reliabel atau dapat diandalkan. Sebaliknya jika nilai Cronbach Alpha < 0,70 maka butir pertnyaan tidak reliabel (Ghozali, 2013).

Uji normalitas adalah uji yang dilakukan untuk melihat apakah data yang digunakan berdistribusi normal atau tidak. Moedel regersi yang baik baik adalah memiliki data distribusi normal. Uji normalitas yang digunakan adalah Kolmogorov-Smirnov testdengan menggunakan nilai signifikan $5 \%(0,05)$. 


\section{Uji Asumsi Klasik}

Dasar pengambilan keputusan dalam penelitian ini adalah jika Tolerance Value $<0,10$ atau VIF > 10 maka terjadi Multikolinieritas. Sebaliknya, jika Tolerance Value $>0,10$ atau VIF $<10$ maka tidak terjadi multikolinieritas pada data yang dikelola.

Model yang baik adalah homoskedastisitas atau tidak terjadinya heteroskedastisitas. Uji heteroskedastisitas dengan uji Glejser diperoleh hasil nilai koefisien masing-masing variabel independen tidak signifikan $(\mathrm{p}>0,05)$ terhadap residual.

\section{Uji Hipotesis}

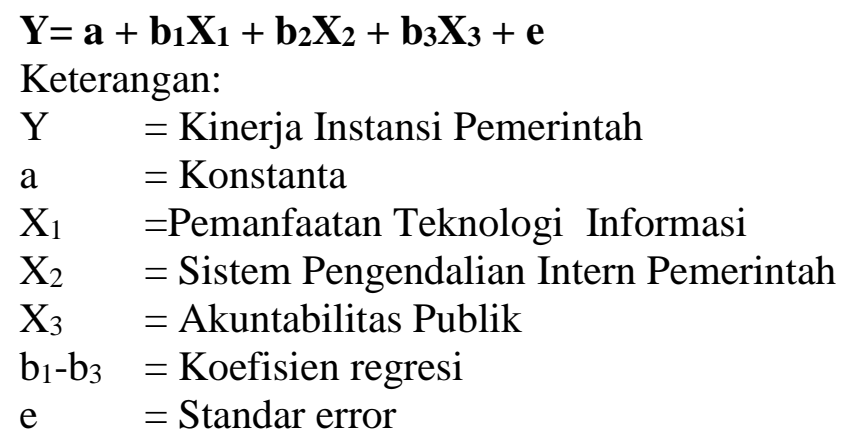

\section{Uji F}

Penetapan untuk mengetahui hipotesis diterima atau ditolak yaitu dengan melihat nilai probabilitas (probabilities value). Jika probabilities value $>$ derajat keyakinan $(0,05)$ maka $\mathrm{H}$ diterima dan Ha ditolak. Artinya variabel independen secara bersama-sama tidak mempengaruhi variabel dependen secara signifikan. Sebaliknya, jika probabilities value < derajat keyakinan $(0,05)$ maka $\mathrm{H} 0$ ditolak dan Ha diterima, artinya variabel independen secara bersama-sama mempengaruhi variabel dependen secara signifikan.

\section{Uji $\mathbf{R}^{2}$}

Uji koefisien determinasi mengukur seberapa jauh kemampuan model dalam menerangkan variasi variabel dependen. Nilai $R^{2}$ adalah antara nilai 0 dan 1 . Nilai $R^{2}$ yang kecil menunjukan kemampuan variabel-variabel independen dalam menjelaskan variasi variabel dependen sagat terbatas. Jika nilai $\mathrm{R}^{2}$ mendekati 1 maka variabel-variabel independen memberikan variasi variben dependen. Semakin tinggi nilai Adjusted- $R^{2}$ maka semakin tinggi variabel inependen menjelaskan variasi variabel dependen (Ghozali, 2013).

\section{Uji-t}

Uji tyaitu untuk menguji apakah variabel independen, secara individu berpengaruh terhadap variabel dependen. Adapun kriteria pengujian hipotesis adalah sebagai berikut: Jika nilai $t$ hitung $>t$ tabel atau nilai Sig<alpha 0,05 maka H0ditolak dan Ha diterima artinya variabel independen secara individual mempengaruhi variabel dependen. Sebalikanya jika nilai $\mathrm{t}_{\text {hitung }}<$ $\mathrm{t}$ tabelatau nilai Sign >alpha 0,05 maka H0 diterima dan Ha ditolak. 


\section{HASIL DAN PEMBAHASAN}

\section{Uji Validitas}

Semua item intrumen kuisioner memiliki nilai signifikansi masing-masing variabel lebih kecil dari 0,349 berarti bahwa alat ukur dalam penelitian ini adalah valid.

\section{Uji Reliabilitas}

Semua variabel memiliki nilai koefisien Alpha Cronbach lebih besar dari 0,7 sehingga dapat dikatakan instrumen pertanyaan yang digunakan dalam penelitian ini sudah reliabel.

\section{Uji Asumsi Klasik}

\section{Hasil Uji Asumsi Klasik}

\begin{tabular}{l|c|c|c}
\hline \multicolumn{1}{c|}{ Variabel } & Hasil & Persyaratan & Keterangan \\
\hline Normalitas & 0,322 & Sig $>0,05$ & Distribusi Normal \\
\hline Multikolinearitas & Toleransi $>0,1$ dan VIF $<$ & Toleransi $>0,1$ dan VIF $<10$ & $\begin{array}{c}\text { Bebas } \\
\text { Multikolinearitas }\end{array}$ \\
\hline Heteroskedastisitas & Sig $>0,05$ & Sig $>0,05$ & $\begin{array}{c}\text { Bebas } \\
\text { Heteroskedastisitas }\end{array}$ \\
\hline
\end{tabular}

Sumber : Data primer diolah, 2017

\section{Pengaruh Pemanfaatan Teknologi Informasi Terhadap Kinerja Instansi Pemerintah}

Berdasarkan hasil uji hipotesis dapat disimpulkan bahwa pemanfaaatan teknologi informasi berpengaruh positif signifikan terhadap kinerja OPD Kota Bengkulu. Berdasarkan statistik deskrptif juga dapat disimpulkan bahwa OPD Kota bengkulu telah dapat memanfaatkan teknologi informasi dengan baik karena nilai rata-rata aktual lebih besar dari nilai rata-rata teoritis. Semakin tinggi pemanfaatan teknologi informasi maka akan meningkatkan kinerja instansi yang dihasilkan. Teknologi yang dimaksud dalam penelitian ini adalah penggunaan sofware atau perangkat dan jaringan internet yang digunakan instansi dalam menjalankan kegiatan ataupun program intansi pemerintah. Dengan demikian, pemanfaatan teknologi informasi yang digunakan intansi dapat dikatakan berperan penting dalam mejalankan kegiatan ataupun program-program instansi Kota bengkulu. Hasil penelitian ini didukung hasil penelitian dari Irine Chintya (2015) yang menyatakan bahwa pemanfaaatan teknologi informasi berpengaruh terhadap kinerja instansi pemerintah daerah.

\section{Pengaruh Sistem Pengendalian Intern Pemerintah Terhadap Kinerja Instansi Pemerintah}

Berdasarkan hasil dari uji hipotesis dapat disimpulkan bahwa sistem pengendalian intern pemerintah berpengaruh positif signifikan terhadap kinerja instansi pemerintah. Berdasarkan hasil dari analisis statistik deskriptif dalam penelitian ini dapat disimpulkan bahwa sistem pengendalian intern pemerintah telah berjalan dengan baik, artinya penerapan pengendalian intern pada OPD Kota Bengkulu telah terlaksana secara efektif karena nilai ratarata aktual yang di peroleh lebih besar dari nilai rata-rata teoritis.Maka dengan adanya pengendalian inter pemerintah seluruh kegiatan atau proses kegiatan pengawasan lain terhadap organisasi dalam rangka memberikan keyakinan yang memadai bahwa kegiatan telah dilaksanakan dengan tolak ukur yang telah ditetapkan secara efektif dan efesien untuk kepentingan dalam mewujudkan tata peerintahan yang baik. 


\section{Pengaruh Akuntabilitas Publik Terhadap Kinerja Instansi Pemerintah}

Berdasarkan hasil uji hipotesis dapat disimpulkan bahwa akuntabilitas publik berpengaruh positif signifikan terhadap kinerja OPD Kota Bengkulu dan berdasarkan hasil dari analisis deskriptif akuntabilitas publik memiliki nilai rata-rata aktual yang diperoleh lebih besar dari nilai rata-rata teoritis dan dapat disimpulkan bahwa akuntabilitas publik pada OPD kota Bengkulu sudah terlaksana dengan baik.Maka dengan adanya penerapan akuntabilitas publik yang baik pihak internal maupun eksternal dapat meraakan manfaat dari kegiatan yang telah terlaksana sesuai dengan yang telah dianggarkan. Dimana dengan adanya akuntabilitas publik yang tinggi akan memeberikan pertanggungjawaban atas semua kegiatan yang dilaksanakan sehingga kinerja pemerintah daerah dapat dilinilai baik pihak internal maupun pihak eksternal. Dengan demikian hubungan antara akuntabilitas publik dan kinerja instansi pemerintah adalah semakin baik penerapan akuntabilitas publik pada instansi pemerintah akan semakin baik pula kinerja instansi pemerintah.

\section{PENUTUP}

\section{Simpulan}

Penelitian ini bertujuan untuk menguji apakah pemanfaatan teknologi informasi, sistem pengendalian intern pemerintah dan akuntabilitas publik berpengeruh terhadap kinerja OPD di Kota Bengkulu. Berdasarkan hasil penelitian yang telah dilakukan, maka dapat disimpulkan beberapa hal, antara lain sebagai berikut:

1. Pemanfaatan teknologi informasi berpengaruh positif terhadap kinerja OPD Kota Bengkulu. Hal ini menunjukan bahwa semakin baik penggunaan teknologi informasi maka akan membantu kinerja OPD dalam meningkatkan kinerjanya.

2. Sistem pengendalian intern Pemerintahberpengaruh positif terhadap kinerja pada OPD Kota Bengkulu. Hal ini menunjukkan bahwa semakin tinggi tingkat penerapan pengendalian intern pemerintah maka akan semakin baik pula kinerja OPD.

3. Akuntabilitas publik berpengaruh positif terhadap kinerja OPD Kota Bengkulu. Hal ini menunjukkan bahwa semakin tinggi tingkat akuntabilitas publikOPD, maka akan semakin baik pula kinerja OPD.

\section{Saran}

Penulis sadar bahwa masih banyak kekurangan peneliti dalam melakukan penelitian, saranyang dapatpenulis berikan dalampenelitian iniadalah :

1. Objek penelitian sebaiknya diperluas, misalnya Organisasi Perangkat Daerah Provinsi Bengkulu. Sehingga hasil yang diperoleh lebih maksimal dan lebih dapat memberikan gambaran yang lebih jelas mengenai pengaruh pemanfaatan teknologi informasi, sistem pengendalian intern pemerintah dan akuntabilitas publik terhadap kinerja instansi pemerintah secara menyeluruh.

2. Untuk penelitian selanjutnyasebaiknya dalam penelitian menambahas variabel independen yang memungkinkan dalam mempengaruhi kinerja instansi pemerintah. Misalnya variabel kompetensi SDM yang ada,budaya organisasi,komitmen pegawai, dan ketaatan terhadap peraturan perundangandan lain sebagainya.

\section{Implikasi Penelitian}

Berdasarkan hasil penelitian dan kesimpulan di atas maka penelitian memiliki implikasi sebagai berikut: 
1. Hasil penelitian ini bisa bermanfaat bagi OPD Kota Bengkulu dengan hasil penelitian ini, bisa menjadi bahan masukan apa saja faktor-faktor yang memepengaruhi kinerja pada OPD Kota Bengkulu. Karena hasil penelitian ini menemukan pemanfaatan teknologi informasi, sistem pengendalian intern pemerintah dan akuntabilitas publik yang baik pada OPD, akan Meningkatkan kinerja pada OPD Kota Bengkulu.

2. Hasil penelitian ini diharapkan dapat bermanfaat bagi OPD dalam mempertahankan kinerja yang baik.

3. Hasil penelitian ini dapat menjadi referensi bagi peneliti selanjutnya yang tertarik meneliti dan mengkaji permasalahan yang sama.

\section{Keterbatasan Penelitian}

Penelitian ini masih jauh dari kata sempurna karena memiliki keterbatasan penelitian diantaranya:

1. Data dalam penelitian ini yang hanya dapat dikumpulkan dari responden yang diteliti ada sebanyak 32 dari 38 OPD Kota Bengkulu. Seharusnya peneliti dapat mengumpulkan data dari keseluruhan responden yang ada pada OPD Kota Bengkulu. Keterbatasan ini terkendala karena adanya kuisioner yang hilang dan ketersediaan responden dalam mengisi kuisioner.

2. Penelitian ini menggunakan metode penyebaran kuisioner tanpa dilengkapi dengan wawancara atau pertanyaan lisan. Keterbatasan yang melekat pada data yang diperoleh yaitu adanya perbedaan persepsi penulis dengan responden dalam penelitian.

\section{DAFTAR PUSTAKA}

Achmadi, Indra. 2012. “Kinerja Organisasi”. Diakses 29 Desember 2016. Indraachmadi.blogspot.co.id/2012/04/kinerja-organisasi.html?=1.

Arifin, Andiza Z. 2014. Pengaruh budaya organisasi dan akuntabillitas publik terhadap kinerja organisasi publik (studi pada rumah sakit daerah massenrempulu, Kabupaten Enrekang).Skripsi. Jurusan Akuntansi Fakultas Ekonomi dan Bisinis. Universitas Hasanuddin.

Bastian, Indra, Ph.D. 2001. Akuntansi Sektor Publik Indonesia. Yogyakarta: BPFE.

Chintya, Irine. 2015. Pengaruh Pemanfaataan Teknologi Informasi Dan Sistem Pengendalian Intern Pemerintah Terhadap Kinerja Instansi Pemerintah Di Kota Solok. Padang: Jurnal Akuntansi.

Ghozali, I. 2013. Aplikasi Analisis Multivariate Dengan Program IBM SPSS 21 Halim, Abdul dan Muhammmad Syam Kusufi. 2013. Akuntansi Sektor Publik. Jakarta: Salemba empat.

Harimurti, Yohanes. 2004. Problematika Suatu Instansi Pemerintah Dalam Menyususn Indikator Kinerja Tinjauan Dan Dimensi Value For Money. Jurnal Akuntansi Dan Keuangan Sektor Publik.

Mahmudi. 2005. Manajemen Kinerja Sektor Publik. Yogyakarta: UPP AMP YKPN.

Mahmudi. 2007. Manajemen Kinerja Sektor Publik, edisi revisi. Yogyakarta: UPP STIM YKPN.

Mahoney, et, al. 1963. Development Of Managerial Performance: A Research Approach. Cincinnati: South Western Publishing.

Mahsun, Mohammad. 2006. Pengukuran Kinerja Sektor Publik. Edisi Pertama. Yogyakarta: BPFE Yogyakarta.

Mahsun, Moh. 2011. "Akuntabilitas Kinerja”. Diakses 2 Januari 2017. mohmahsun.blogspot.co.id/2011/04/akuntabilitas-kinerja.html?=1. 
Mardiasmo. 2002. Akuntansi Sektor Publik. Yogyakarta: Andi Yogyakarta

Mardiasmo. 2009. Akuntansi Sektor Publik. Yogyakarta: CV Andi Offset.

Martin, E.W. CW Brown, D.W. DeHayes, J.A. Hoffer, dan W.C Perkins. 2005. Managing Information Technology. New Jersey: Prentice- Hall, Inc.

Nagawa, koori. 2012. "Akuntabilitas Publik (Public Countability) Sebagai Pilar Good Governance". $\quad$ Diakses $25 \quad$ Juli 2017. https://administrasinegaraku.blogspot.co.id/2012/07/akuntabilitaspublikpublic.html

Nasir, Azwir, and Ranti Oktari. 2010. Pengaruh Pemanfaatan Teknologi Informasi Dan Pengendalian Intern Terhadap Kinerja Instansi Pemerintah (Studi Pada Satuan Kerja Perangkat Daerah Kabupaten Kampar).Skripsi. Jurusan Akuntansi Fakultas Ekonomi. Unversitas Riau.

Nasir, Azwir, dan Ranti Oktari. 2013. Pengaruh Pemanfaatan Teknologi Informasi Dan Pengendalian Intern Terhadap Kinerja Instansi Pemerintah (Studi Pada Satuan Kerja Perangkat Daerah Kabupaten Kampar).Jurnal Ekonomi.

Peraturan Pemerintah No. 18 Tahun 2016. Pedoman penyusunan, pengendalian dan evaluasi rencana kerja pemerintah daerah tahun 2017.

Pemerintah Republik Indonesia. 2008. Peraturan Pemerintah Nomor 60 Tahun 2008 Tentang Sistem Pengendalian Internal Pemerintah.

Putra, Deki. 2013. Pengaruh Akuntabilitas Publik Dan Kejelasan SasaranAnggaran Terhadap Kinerja ManajerialSatuan Kerja Perangkat Daerah (studi empiris pada satuan kerja perangkat daerah kota padang). Jurnal Akuntansi.

Rahadi. 2007.PerananTeknologiInformasidalampeningkatanpelayanandi sektor publik. Seminar NasionalTeknologi. Yogyakarta.

Rai, I G.A. 2011. Audit Kinerja pada Sektor Publik. Jakarta: Salemba Empat.

Riadi, Muchlisin. 2014. "Pengertian, indikator dan faktor yang mempengaruhi kinerja". Diakses 19 Februari 2017. www.kajianpustaka.com/2014/01/pengertian-indikatorfaktor-mempengaruhi-kinerja.html? $m=1$.

Solikhin, Akhmad. 2006. Penggabungan Laporan Keuangan dan Laporan Kinerja Instansi Pemerintah: Perkembangan dan Permasalahan. Jurnal Akuntansi Pemerintah.

Sugiyono, Drs. 2010. Metode penelitian pendidikan. Pendekatan kuantitatif.

Surakhmad, Winarno. 2004. Metodologi Penelitian.

Syaifullah, 2013. Penerapan Teknologi Informasi Di Bidang Pemerintahan. Di akses 25 Juli 2017. http://sumbawabaratnews.com/?p=8662

Wansyah H, Darwanis dan Bakar U. 2012. Pengaruh Kapasitas Sumber Daya Manusia, Pemanfaatan Teknologi Informasi dan Kegiatan Pengendalian terhadap Nilai Informasi Pelaporan Keuangan SKPD pada Provinsi Aceh. Jurnal Akuntansi. Vol. 1 No. 1, Agustus, hal 43-58.

Widyaningrum, Celviana, Rahmawati. 2010. Pemgaruh SDM, dan Pemanfaatan Teknologi Informasi terhadap Keterandalan dan Ketepatwaktuan Pelaporan Keuangan Pemerintah Daerah dengan Variable Intervening Pengendalian Internal Akuntansi, Studi Empiris di Pemda Subosukawonosraten. Simposium Nasional Akuntansi XII Purwokerto.

Wilkinson, W. Joseph, Michael J. Cerullo, Vasant Raval, \& Bernard Wong-On-Wing. 2000. Accounting Information Systems: Essential Concepts and Applications. Fourth Edition. John Wiley and Sons. Inc.

Yosefrinaldi. 2013. Pengaruh Kapasitas Sumber Daya Manusia Dan Pemanfaatan Teknologi Informasi Terhadap Kualitas Laporan Keuangan Pemerintah Daerah Dengan Variabel Intervening Sistem Pengendalian Internal Pemerintah (Studi Empiris Pada Dinas Pengelolaan Keuangan Dan Aset Daerah Se-Sumatera Barat).Skripsi Universitas Negeri Padang: Sumatera Barat. 